\title{
PENGARUH GERHANA MATAHARI TOTAL (GMT) TERHADAP PROSES MEKAR BUNGA TERATAI (Nymphaea alba)
}

\author{
Ari Sugiarto \\ Students of Biology Department, Faculty of Mathematics and Natural Sciences, Sriwijaya University.
}

\begin{abstract}
ABSTRAK
Gerhana Matahari adalah peristiwa ketika terhalanginya cahaya Matahari oleh Bulan sehingga tidak semuanya sampai ke Bumi. Peristiwa yang merupakan salah satu akibat dinamisnya pergerakan posisi Matahari, Bumi, dan Bulan ini hanya terjadi pada saat fase bulan baru dan dapat diprediksi sebelumnya. Diprediksi Gerhana Matahari Total (GMT) akan terjadi di Indonesia pada tanggal 9 Maret 2019. Proses mekar dan menutupnya bunga Teratai, seperti Nymphaea alba dipengaruhi oleh besar dan kecilnya intensitas cahaya Matahari. Pengematan dilakukan pada tanggal 6 Maret (hari biasanya) dan 9 (saat terjadi GMT) Maret 2016 pada kawasan persawahan di desa Serdang Menang, pengamatan dilakukan secara manual dan menggunakan mistar untuk mengukur diameter mekarnya bunga tertai. Hasil pengamatan menunjukkan terjadi perbedaan diameter mekar bunga, diameter mekar bunga saat GMT lebih kecil dari pada hari biasanya. Pada hari biasanya, diamter mekar bunga pada pukul 06.15 WIB $0 \mathrm{~cm}, 06.45$ WIB $0.4 \mathrm{~cm}, 07.15$ WIB $5.2 \mathrm{~cm}, 07.45$ WIB $10.7 \mathrm{~cm}, 08.15$ WIB $13.6 \mathrm{~cm}, 08.45$ WIB $14.3 \mathrm{~cm}$, dan 09.15 WIB $15.2 \mathrm{~cm}$. Pada hari terjadinya GMT, diamter mekar bunga pada pukul 06.15 WIB $0 \mathrm{~cm}, 06.45$ WIB $0.2 \mathrm{~cm}, 07.15$ WIB $1.3 \mathrm{~cm}, 07.45$ WIB $8.1 \mathrm{~cm}, 08.15$ WIB $13,6 \mathrm{~cm}$, 08.45 WIB $14.3 \mathrm{~cm}$, dan 09.15 WIB $15.2 \mathrm{~cm}$. Terjadinya GMT mempengaruhi diameter mekar bunga Teratai ( $N$. alba), ini dikarenakan terjadinya penurunan jumlah intesitas cahaya pada saat terjadinya GMT yang menyebabkan diameter mekar bunga saat GMT lebih kecil dari pada hari biasanya.
\end{abstract}

Kata kunci: Gerhana matahari total (GMT) dan Bunga Teratai (Nymphaea alba)

\section{PENDAHULUAN}

Gerhana Matahari adalah peristiwa ketika terhalanginya cahaya Matahari oleh Bulan sehingga tidak semuanya sampai ke Bumi. Peristiwa yang merupakan salah satu akibat dinamisnya pergerakan posisi Matahari, Bumi, dan Bulan ini hanya terjadi pada saat fase bulan baru dan dapat diprediksi sebelumnya. Pada tahun 2016 ini diprediksi terjadi lima kali gerhana, yaitu Gerhana Matahari Total (GMT) 9 Maret 2016 yang dapat diamati dari Indonesia pukul 07.15 WIB, Gerhana Bulan Penumbra (GBP) 23 Maret 2016 yang diamati dari Indonesi, Gerhana Bulan Penumbra (GBP) 18 Agustus 2016 yang diamati dari Indonesia, Gerhana Matahari Cincin (GMC) 1 September 2016 yang tidak dapat diamati dari Indonesia, dan Gerhana Bulan Penumbra (GBP) 16-17 September 2016 yang dapat diamati dari Indonesia [1].

Fenomena Gerhana Matahari total (total solar eclipse) hanya bisa terjadi dalam kurun waktu 100 tahun, sampai saat ini penelitian terkait fenomena alam tersebut sangat menarik untuk dilakukan terutama berkaitan dengan proses metabolisme yang terjadi pada tumbuhan hijau atau tingkat tinggi. Perubahan kondisi lingkungan yang terkait dengan fenomena energi matahari pada tumbuhan sangat berpengaruh pada proses fotosintesis disetiap tumbuhan berdaun hijau. Proses ini juga dipicu oleh perpindahan variasi cahaya matahari dari siang dan malam dengan perbedaan keadaan suhu lingkungan [2].

[3] Gerhana Matahari berdampak terhadap penurunan kecepatan gravitasi Bumi. [4] Penurunan intensitas cahaya Matahari dari dampak Gerhana Matahari berdampak terhadap gerakan menutup daun Bauhinia purpurea. [5] Intensitas cahaya matahari mempengaruhi pertumbuhan tumbuhan. [6] Perbedaan warna cahaya berdampak pada perbedaan pertumbuhan tanaman Krisan (Crhysantemum).

Teratai merupakan tumbuhan liar di habitat alami, yang tidak asing bagi masyarakat Indonesia. Sebagian masyarakat Indonesia hanya mengetahui keelokan tumbuhan tersebut, ternyata disamping keelokannya, teratai juga memiliki manfaat untuk menyembuhkan berbagai penyakit, seperti darah tinggi (hipertensi), keputihan (leucorrhea), radang kulit bernanah (impetigo), gangguan lambung, dan sebagainya. Tumbuhan teratai khususnya pada bagian bunga memiliki kandungan kimia seperti quercetrin [7].

Dampak dari Gerhana Matahari Total (GMT) yang menurunkan intensitas cahaya Matahari tentunya akan berdampak terhadap proses mekarnya bunga. Salah satu bunga yang di perkirakan terpengaruh dari penurunan intensitas cahaya Matahari yaitu bunga Teratai. Diperkirakan proses mekar dan menutupnya bunga Teratai (Nymphaea alba) dipengaruhi oleh besar dan 
kecilnya intensitas cahaya Matahari. Perlu adanya penelitian tentang pengaruh Gerhana Matahari Total (GMT) terhadap proses mekarnya bunga Teratai (Nymphaea alba) untuk membuktikan bahwa proses mekarnya dipengaruhi oleh cahaya Matahari dan seberapa besar pengaruhnya terhadap proses mekarnya bunga Teratai (Nymphaea alba).

\section{METODE PENELITIAN}

Penelitian ini dilakukan pada tanggal 6 dan 9 Maret 2016. Bertempat di Desa Serdang Menang, Kecamatan Sirah Pulau Padang, Kabupaten Ogan Komering Ilir, Provinsi Sumatera Selatan. Informasi yang diperoleh dari LAPAN menunjukkan wilayah Sumatera Selatan dilalui oleh gerhana matahari total (GMT) pada pukul 07.15 WIB. Alat yang dipakai pada penenlitian ini yaitu alat tulis, buku catatan, camera, dan mistar. Pengematan dilakukan secara manual dengan menggunakan mistar untuk mengukur diameter mekarnya bunga tertai. Pengamatan waktu mekarnya Teratai (Nymphaea alba) dilakukan dalam rentan waktu setiap 30 menit. Pengamatan dimulai pada pukul 06.15 WIB - 09.15 WIB. Data pengamatan pada tanggal 6 Maret 2016 (pada hari biasanya) dijadikan sebagai faktor pembanding untuk membandingkan data yang didapat pada tanggal 9 Maret 2016 (Pada saat hari terjadinya Gerhana Matahari Total (GMT)), kedua data tersebut dimuat dalam bentuk tabel dan grafik batang untuk melihat perbedaannya. Bunga Teratai yang diamati pada tanggal 6 dan 9 Maret adalah bunga yang sama.

\section{HASIL DAN PEMBAHASAN}

Berdasarkan hasil pengamatan yang telah dilakukan didapatkan hasil yaitu:

Tabel 1. Diameter mekar bunga Teratai () pada hari biasanya dan saat hari Gerhana Matahari Total (GMT).

\begin{tabular}{llllllll}
\hline & \multicolumn{7}{c}{ Diamater Mekar Bunga } \\
\cline { 2 - 8 } Pengamat & 06. & 06. & 07. & 07. & 08.1 & 08.4 & 09.15 \\
an & 15 & 45 & 15 & 45 & 5 & 5 & WIB \\
& WI & WI & WI & WI & WIB & WI & \\
& B & B & B & B & & B & \\
\hline Pada Hari & 0 & 0,4 & 5,2 & 10, & 13,6 & 14,3 & 15,2 \\
Biasanya & $\mathrm{cm}$ & $\mathrm{cm}$ & $\mathrm{cm}$ & 7 & $\mathrm{~cm}$ & $\mathrm{~cm}$ & $\mathrm{~cm}$ \\
& & & & $\mathrm{~cm}$ & & & \\
\hline $\begin{array}{l}\text { Pada Hari } \\
\text { Saat }\end{array}$ & 0 & 0,2 & 1,3 & 8,1 & 13,6 & 14,3 & 15,2 \\
$\begin{array}{l}\text { Gerhana } \\
\text { Matahri }\end{array}$ & $\mathrm{cm}$ & $\mathrm{cm}$ & $\mathrm{cm}$ & $\mathrm{cm}$ & $\mathrm{cm}$ & $\mathrm{cm}$ & $\mathrm{cm}$ \\
Total & & & & & & & \\
\hline
\end{tabular}

Berdasarkan pengamatan yang telah dilakukan didapat bahwa pada waktu gerhana Matahari memang mempengaruhi proses mekarnya bunga
Teratai (Nymphaea alba), ini dibuktikan dengan tabel hasil pengamatan (Tabel 1) pada pukul 06.45 WIB samapai dengan pukul 07.45 WIB terlihat jelas perbedaan diameter bunga. Pukul 06.45 WIB sampai dengan pukul 07.45 WIB merupakan waktu terjadinya gerhana Matahari. Gambar perbedaan dimeter bunga pada hari biasanya dan saat terjadi GMT dapat dilihat pada Gambar 1 dan 2.
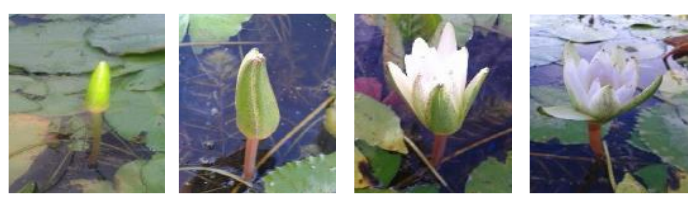

(06.15 WIB) $(06,45 \mathrm{WIB})(07.15 \mathrm{WIB})(07.45$

WIB)
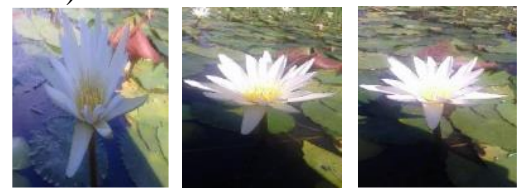

(08.15 WIB) (08.45 WIB) (09.15 WIB)

Gambar 2. Diameter mekar bunga pada hari biasanya
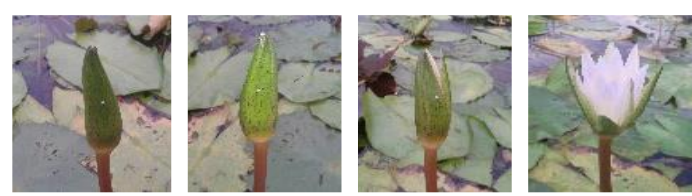

(06.15 WIB) (06.45 WIB) (07.15 WIB) $(07.45$

WIB)
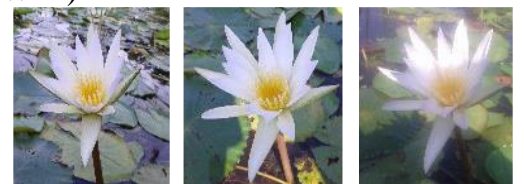

(08.15 WIB) (08.45 WIB) (09.15 WIB)

Gambar 3. Diameter mekar bunga pada hari terjadinya Gerhana Matahari Total (GMT)

Diameter mekar bunga Teratai (Nymphaea alba) pada hari biasanya pada pukul 06.15 WIB $0 \mathrm{~cm}$, pukul 06.45 WIB diameter mekar bunga $0,4 \mathrm{~cm}$, pukul 07.15 WIB diameter mekar bunga $5,2 \mathrm{~cm}$, pukul 07.45 WIB diameter mekar bunga $10,7 \mathrm{~cm}$, pukul 08.15 WIB diameter mekar bunga 13,6 cm, pukul 08.45 WIB diameter mekar bunga $14,3 \mathrm{~cm}$, dan pada pukul 09.15 WIB diameter mekar bunga $15,2 \mathrm{~cm}$. Sedangkan pada hari terjadinya gerhana Matahari diameter mekar bunga Teratai (Nymphaea alba) pukul 06.15 WIB $0 \mathrm{~cm}$, pukul 06.45 WIB diameter mekar bunga $0,2 \mathrm{~cm}$, pukul 07.15 WIB diameter mekar bunga $1,3 \mathrm{~cm}$, pukul 07.45 WIB diameter mekar bunga $8,1 \mathrm{~cm}$, pukul 08.15 WIB diameter mekar bunga 13,6 cm, pukul 08.45 WIB diameter mekar bunga $14,3 \mathrm{~cm}$, dan pada pukul 09.15 WIB diameter mekar bunga 15,2 cm. 


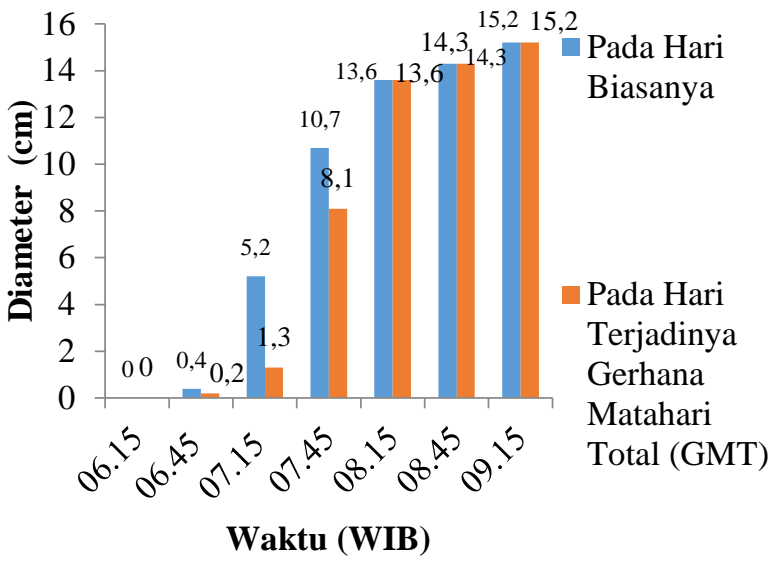

Gambar 3. Grafik perbedaan proses mekar bunga Teratai (Nymphaea alba) pada hari biasanya dan saat hari Gerhana Matahari Total (GMT).

Berdasarkan Gambar 3, perbedaan diamater mekar bunga Teratai pada hari biasanya dan pada hari terjadinya Gerhana Matahari Total (GMT) ini dapat dipengaruhi oleh penurunan intensitas cahaya Matahari dari dampak terjadinya Gerhana Matahari Total (GMT). [5] Intenstitas cahaya matahri mempengaruhi pertumbuhan tumbuhan. [4] Penurunan intensitas cahaya Matahari dari dampak Gerhana Matahari berdampak terhadap gerakan menutup daun.

\section{KESIMPULAN}

Berdasarkan pengamatan yang telah dilakukan didapatkan kesimpulan yaitu Gerhana Matahari Total (GMT) mempengaruhi proses mekarnya bunga Teratai (Nymphaea alba) yang terlihat dari perbedaan diamater mekar bunga pada saat hari terjadinya Gerhana Matahari Total (GMT) dan pada hari biasanya. Pada hari saat Gerhana Matahari Total (GMT) proses mekarnya bunga Teratai (Nymphaea alba) akan lebih lambat dari hari biasanya.

\section{DAFTAR PUSTAKA}

[1] Lapan. Gerhana Matahari Total 9 Maret 2016, (Online).

https://www.lapan.go.id/index.php/subblog/read /2015/1345/Gerhana-Matahari-Total-diIndonesia-9-Maret-2016/1290， 2016, Diakses pada tanggal 14 Maret 2018.

[2] Teguh R., Fengky F. A., Hepryand L. D. U., dan Salampak D., Pemantauan Perilaku Tumbuhan Mimosa pudica Terhadap Efek Gerhana Matahari Total Berbasis Wireles Smart Sensor, Prosiding SNRT Politeknik Negeri Banjarmasin, 2016.
[3] Indratno T. K., Ginanjar A. M., dan Widiyaka A., Pengaruh Gerhana Matahari Terhadap Nilai Percepatan Gravitasi Bumi: Sarana Pembelajaran untuk Mendekatkan Fisika pada Kehidupan Sehari-hari, JRKPF UAD, Vol. 3, Issue. 1, 2016, pp.10-12.

[4] Alyasyfi M. N., Dwi G., Robby S., Risky K., Fahmi J., Muhamad G. N., Pengaruh Perubahan Intensitas Cahaya Akibat Gerhana Matahari Sebagian Terhadap Gerak Daun Bauhinia Purpurea, Prosiding Seminar Nasional Fisika (E-Journal) SNF2016, Vol. 5, Issue. 1, 2016, pp. $39-44$.

[5] Khan M. L., Putul B., dan R. S. Tripatih., Effects Of Forest Disturbance On Fruit Set,Seed Dipersal and Predation Of Rudraksh (Elaeocarpus ganitrus Roxb.) In Northeast India, CURRENT SCIENCE, Vol. 88, Issue. 1, 2005, pp. 133-142.

[6] Wiguna I. K. W., I. M. Anom S., dan I. M. Nada., Pertumbuhan Tanaman Krisan (Crhysantemum) Dengan Berbagai Penambahan Warna Cahaya Lampu Led Selama 30 Hari Pada Fase Vegetatif, Bali, Program Studi Teknik Pertanian, Fakultas Teknologi Pertanian,Universitas Udayana, 2015.

[7] Aprilina M. S., Dian P. N., Anggy D. P., dan Retno H., Metode Plester Herbal Berbahan Bunga Teratai (Nelumbium Nelumbo Druce.) Bagi Penderita Impetigo. J. Ilmiah Mahasiswa. Vol. 2, Issue. 2, 2012, pp. 106-110. 